\title{
Rynek pracy województwa dolnośląskiego w okresie spowolnienia gospodarczego
}

Rynek pracy jest rozumiany jako całokształt zagadnień związanych z kształtowaniem podaży i popytu pracy. Sytuacja na wspomnianym rynku jest efektem oddziaływania wielu złożonych procesów. Z jednej strony jest ona pochodną poziomu rozwoju i struktury gospodarki, z drugiej - wpływają na nią zmiany związane z ciagle postępującą integracją Polski z Unią Europejską, a także procesy gospodarcze o charakterze globalnym (Hildebrandt 2003).

Kryzys na rynkach finansowych i bankowych, zapoczątkowany w 2007 r., stał się przyczyną ogólnoświatowego kryzysu gospodarczego. W wypadku Polski kryzys nie przybrał charakteru typowej recesji skutkującej nierzadko spadkiem produktu narodowego brutto, lecz spowodował znaczne obniżanie się jego dynamiki, szczególnie w 2009 r. W związku z tym w opracowaniu w stosunku do polskiej gospodarki w okresie 2007-2009 użyto określenia spowolnienie gospodarcze.

Obszar rynku pracy tworzy zespół różnorodnych elementów, wśród których możemy wyróżnić:

- zasoby kapitału ludzkiego i jego wykorzystanie (np. z punktu widzenia grup wiekowych, wykształcenia);

- struktury pracujących i zatrudnionych w poszczególnych sektorach gospodarki narodowej;

- wielkość i struktury bezrobocia.

W opracowaniu zaprezentowano zagadnienia rynku pracy, których analiza opierała się na dostępnych danych (przede wszystkim z lat 2008-2009), obejmujących podmioty zatrudniające powyżej 9 osób i nieuwzględniających rolników indywidualnych. Przyjęcie takiej zbiorowości do badań wynika z braku publikacji przez GUS pełnych danych dotyczących pracujących i zatrudnienia w układach regionalnych i lokalnych.

\section{AKTYWNOŚĆ EKONOMICZNA LUDNOŚCI}

Badanie aktywności ekonomicznej ludności (BAEL) stanowi podstawowe źródło informacji o sytuacji na rynku pracy. Jego celem jest określenie wielkości i struktury siły roboczej występującej na danym terenie. Podstawą określenia poziomu aktywności ekonomicznej ludności jest ustalenie udziału ludności aktywnej zawodowo w ogólnej liczbie ludności po- 
wyżej 15. roku życia. Zgodnie z definicją GUS, ludność aktywną zawodowo stanowią osoby pracujące i bezrobotne.

W województwie dolnośląskim w latach 2000-2008 zaobserwowano stopniowy spadek wartości wskaźnika aktywności zawodowej z 57,3\% w 2000 r. do 52,9\% w 2008 r. Obniżanie się jego wartości miało miejsce we wszystkich analizowanych w regionie kategoriach ludności (ryc. 1A). Ponadto niskiej aktywności zawodowej kobiet towarzyszy szybszy jej spadek w porównaniu z aktywnością mężczyzn.

Spadek wartości wskaźnika aktywności zawodowej w regionie jest zjawiskiem negatywnym. Jego wartość była niższa od średniej krajowej wynoszącej w 2008 roku 54,2\%. Powyższa różnica ulega jednak stopniowemu zmniejszaniu. W 2009 r. wartość współczynnika aktywności zawodowej ludności województwa dolnośląskiego wynosiła już 53,9\% przy średniej krajowej wynoszącej 54,9\%. Wzrost ten był w znacznej mierze zdeterminowany wzrostem liczby bezrobotnych w regionie, będącym efektem obserwowanego spowolnienia gospodarczego w województwie. Wartość omawianego współczynnika na obszarze województwa była nieco wyższa w mieście niż na wsi. Wyższa też była aktywność zawodowa mężczyzn (62,2\%) niż kobiet (44,6\%).

W wypadku wskaźnika zatrudnienia po okresie spadku jego wartości w latach 20002003 obserwowano stopniowy jego wzrost w następnych latach badanego okresu (ryc. 1B): największy dla mężczyzn (o blisko 13 p.p.), najmniejszy zaś dla kobiet (o 5,4 p.p.). Wskaźnik zatrudnienia uzyskiwał jednak niższe wartości w stosunku do współczynnika aktywności zawodowej. Jego wartość dla województwa wyniosła w 2008 r. 48,1\%. W układzie miasto-wieś wartość wskaźnika zatrudnienia wyniosła odpowiednio: 48,9\% dla miasta i 46,4\% dla obszarów wiejskich. Podobnie wyższy wskaźnik zatrudnienia był charakterystyczny dla mężczyzn $(57,1 \%)$ niż dla kobiet $(40 \%)$.

Wzrost wartości wskaźnika zatrudnienia od roku 2004 był związany z obniżaniem się poziomu bezrobocia w województwie. Zaznaczające się w $2008 \mathrm{r}$. spowolnienie gospodarcze w Polsce nie spowodowało jednak procesu obniżania się poziomu wskaźnika zatrudnienia $\mathrm{w}$ regionie.

Wartości obu wskaźników wykazują znaczne zróżnicowanie w zależności od grup ludności według wieku i poziomu wykształcenia (ryc. 2). Najwyższe wartości występują w grupach wiekowych 25-34, 35-44 i 45-54 lata, czyli w wieku produkcyjnym. W dwóch pierwszych grupach wiekowych poziom wskaźnika aktywności zawodowej kształtował się na poziomie znacznie powyżej $80 \%$, zaś wskaźnik zatrudnienia nie przekraczał wspomnianej wartości. Najniższą aktywność zawodową odnotowano w grupie ludności najstarszej, tj. powyżej 55 roku życia.

Najwyższe wartości obu wskaźników są charakterystyczne dla ludności z wykształceniem wyższym, policealnym i średnim zawodowym oraz zasadniczym zawodowym (ryc. 3). Wysoki poziom wykształcenia oraz kwalifikacji zawodowych skutkuje wyższą aktywnością zawodową ludności i jej zatrudnieniem, o czym świadczą np. niższe wartości wskaźników charakterystyczne dla ludności z wykształceniem średnim ogólnokształcącym czy najniższe wartości obu parametrów wśród ludności najsłabiej wykształconej. 

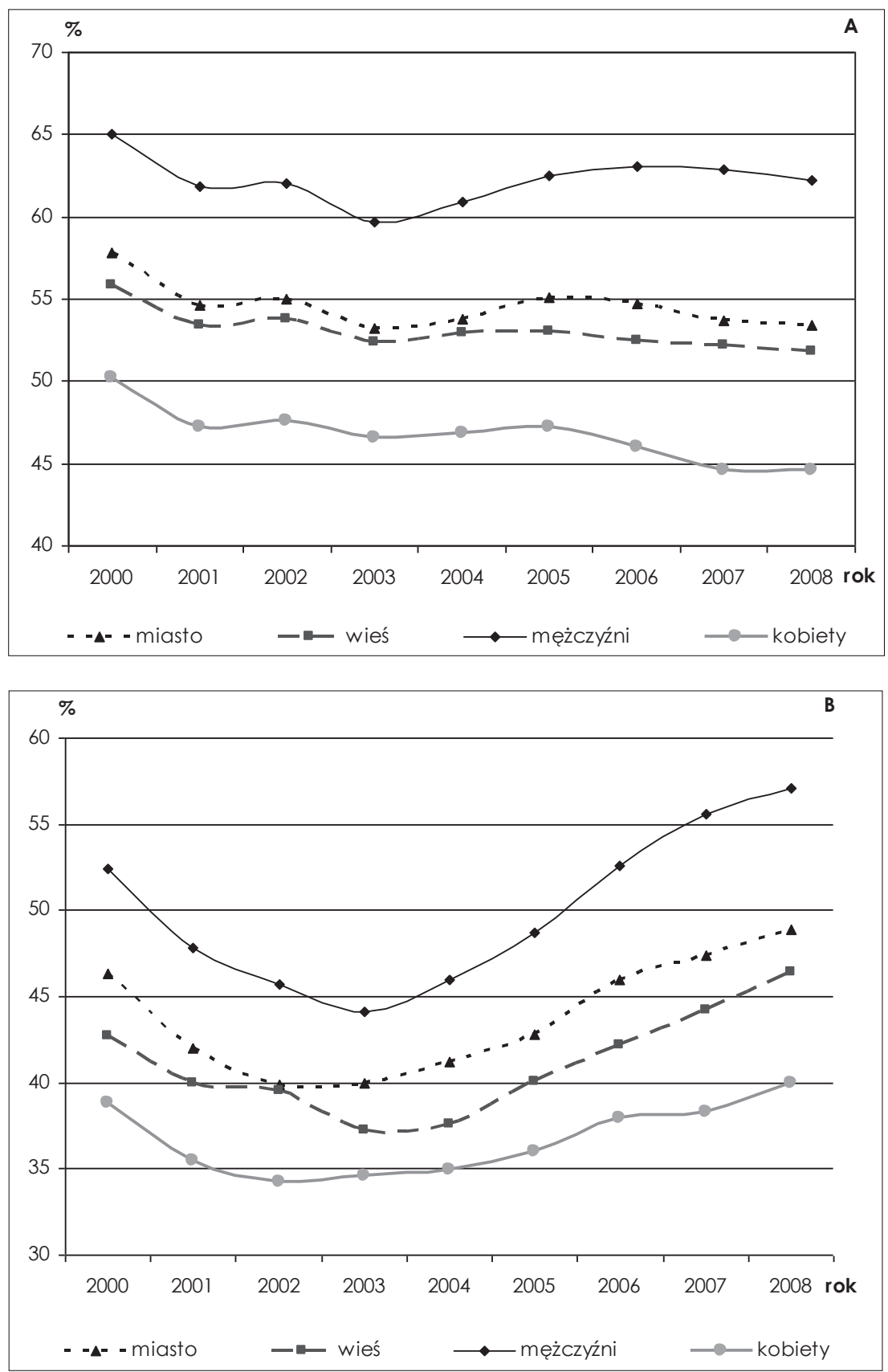

Ryc. 1. Wskaźniki aktywności zawodowej (A) i zatrudnienia (B) w województwie dolnośląskim według płci i miejsca zamieszkania w latach 2000-2008

Źródło: opracowanie własne na podstawie Rocznik Statystyczny... 2003 oraz Województwo dolnoślaskie... $(2005,2006,2008,2009)$ 


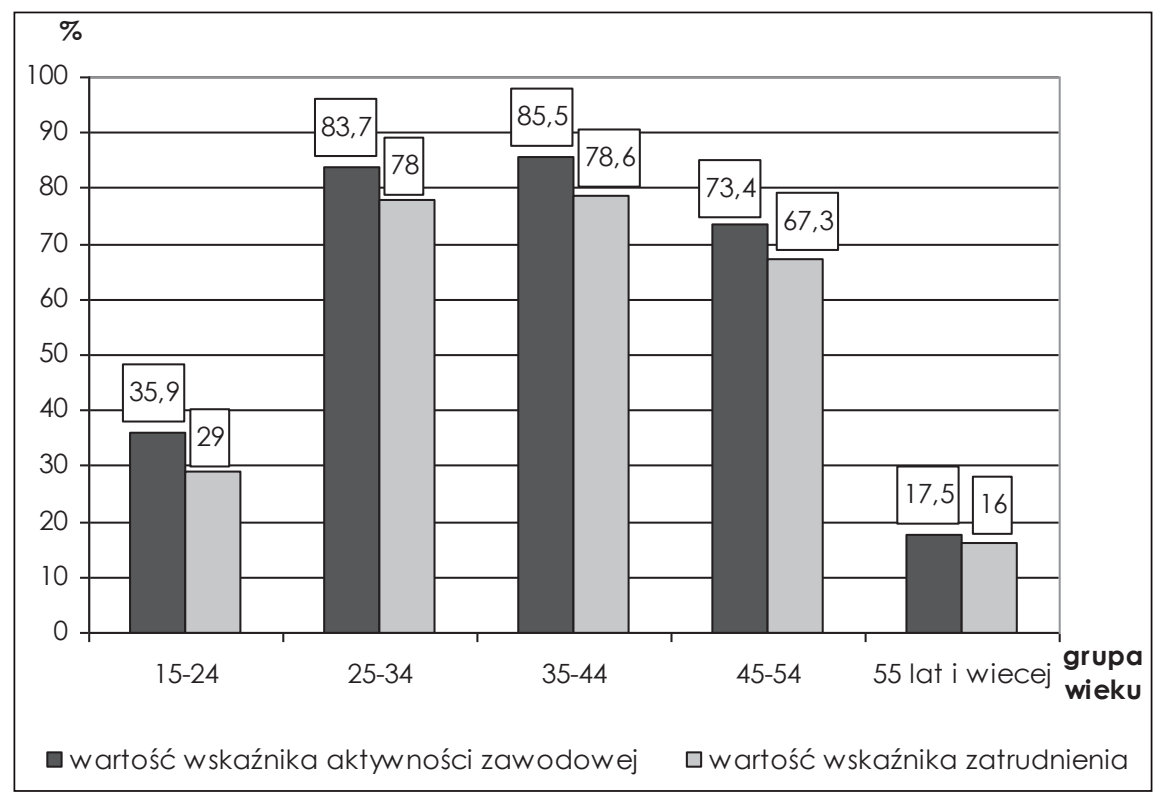

Ryc. 2. Wartość wskaźników aktywności zawodowej ludności i zatrudnienia w województwie dolnośląskim według ekonomicznych grup wieku w 2008

Źródło: opracowanie własne na podstawie Rocznik Statystyczny... 2003 oraz Województwo dolnoślaskie... $(2005,2006,2008,2009)$

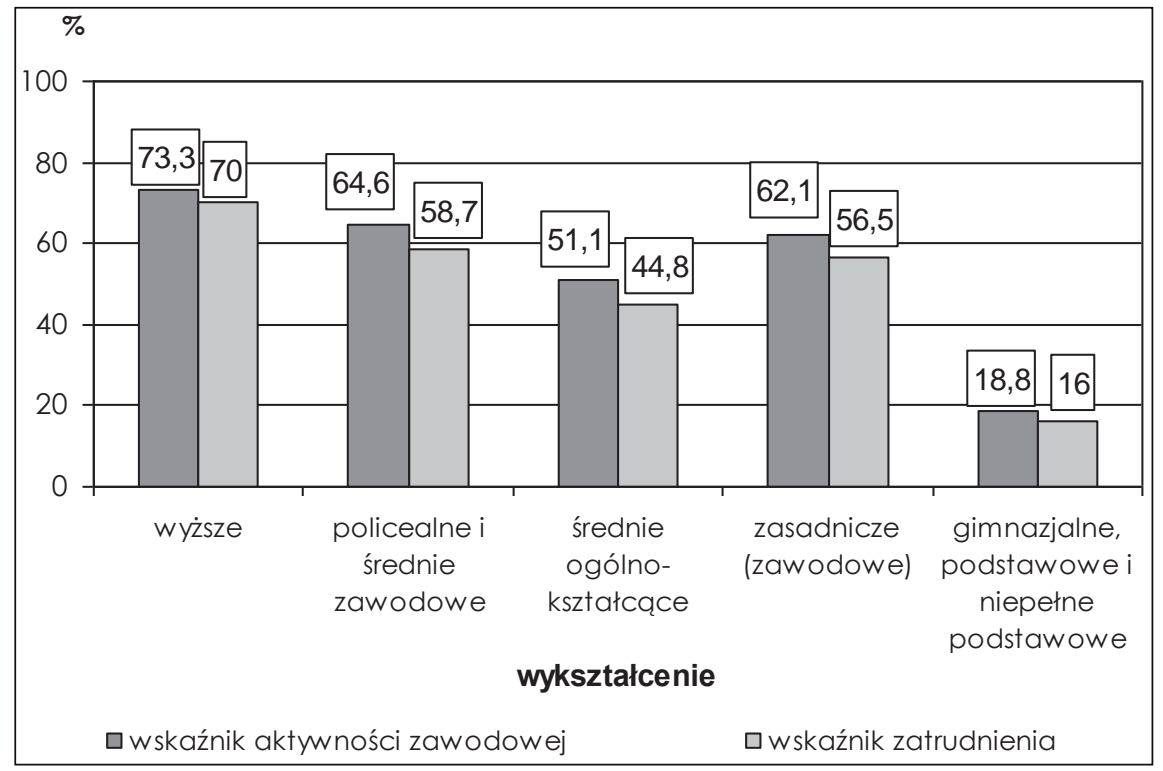

Ryc. 3. Wartość wskaźników aktywności zawodowej ludności i zatrudnienia w województwie dolnośląskim według wykształcenia w 2008

Źródło: opracowanie własne na podstawie Rocznik Statystyczny... 2003 oraz Województwo dolnoślaskie... $(2005,2006,2008,2009)$ 


\section{Pracujący I ZATRUdNiENIE W REgIONIE}

Dane GUS o pracujących dotyczą osób wykonujących pracę przynoszącą zarobek lub dochód i obejmują osoby zatrudnione na podstawie stosunku pracy (umowa o pracę, powołanie, mianowanie lub wybór), pracodawców i pracujących na własny rachunek, osoby wykonujące pracę nakładczą, agentów, członków spółdzielni produkcji rolniczej itp. Dane dotyczące przeciętnego zatrudnienia ujmują wyłącznie zatrudnionych na podstawie stosunku pracy. Informacje dotyczą pracowników pełnozatrudnionych oraz niepełnozatrudnionych w przeliczeniu na pełnozatrudnionych (Województwo dolnoślaskie..., 2009).

Liczba pracujących w regionie uległa stopniowemu wzrostowi od roku 2004 (akcesja Polski do Unii Europejskiej) po okresie spadku w latach 2000-2004 (ryc. 4). Postępujący wzrost w latach 2004-2007 był wynikiem korzystnych przemian w lokalnych gospodarkach regionu związanych początkowo z ogólnoświatową, a później ogólnokrajową koniunkturą gospodarczą. Podobna prawidłowość była charakterystyczna także dla zatrudnienia. Wzrostowi liczby pracujących jak i przeciętnego zatrudnienia towarzyszyło znaczące zmniejszanie się liczby bezrobotnych; poziom bezrobocia obniżył się niemal o połowę.

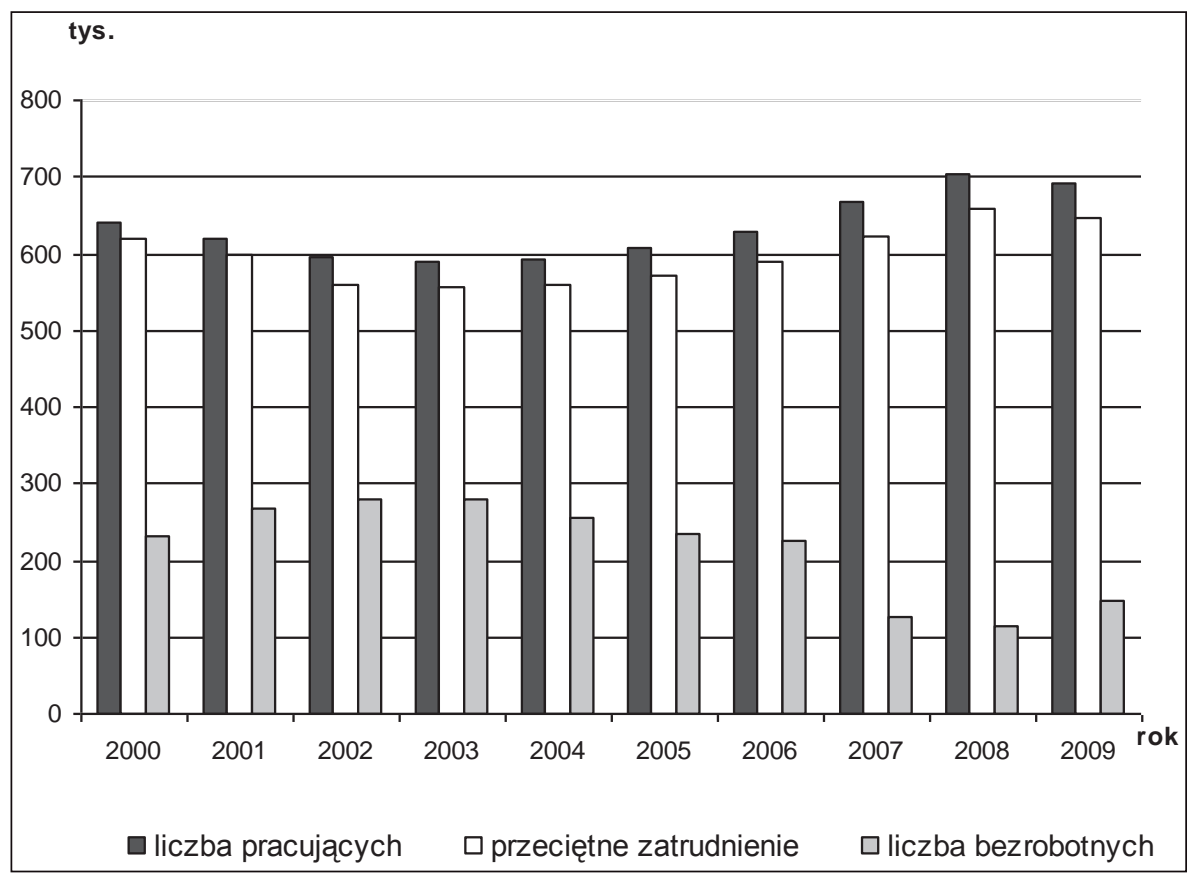

Ryc. 4. Liczba pracujących i zarejestrowanych bezrobotnych w województwie dolnośląskim w latach 2000-2009

Źródło: opracowanie własne na podstawie Rocznik Statystyczny... 2003 oraz Województwo dolnoślaskie... $(2005,2006,2008,2009)$

Pomimo mocno zaawansowanego kryzysu w światowej gospodarce, w Polsce, a także w regionie dolnośląskim w 2008 r. obserwowano korzystne tendencje absorpcji siły roboczej przez rynek pracy i spadek liczby bezrobotnych. Odwrócenie tej korzystnej sytuacji na 
regionalnym rynku pracy ujawniło się dopiero w roku 2009, w którym odnotowano przyrost liczby osób bez pracy. Towarzyszyło temu nieznaczne obniżenie się liczby pracujących i zatrudnionych w stosunku do $2008 \mathrm{r}$.

Analiza nasycenia pracującymi lokalnych gospodarek Dolnego Śląska, mierzona relacją liczby pracujących na 1000 mieszkańców, wskazuje na istotne przestrzenne różnice w układzie powiatów (ryc. 5A). Obszarami o największym natężeniu badanego zjawiska jest powiat polkowicki oraz dwa miasta na prawach powiatu: Wrocław i Legnica. Wysokie wartości wskaźnika charakterystyczne były także dla powiatów wrocławskiego i oławskiego oraz Jeleniej Góry. Na obszarze województwa dolnośląskiego można zaobserwować zaznaczające się dwa obszary koncentracji pracujących. Pierwszy, silniej wykształcony, obejmu-

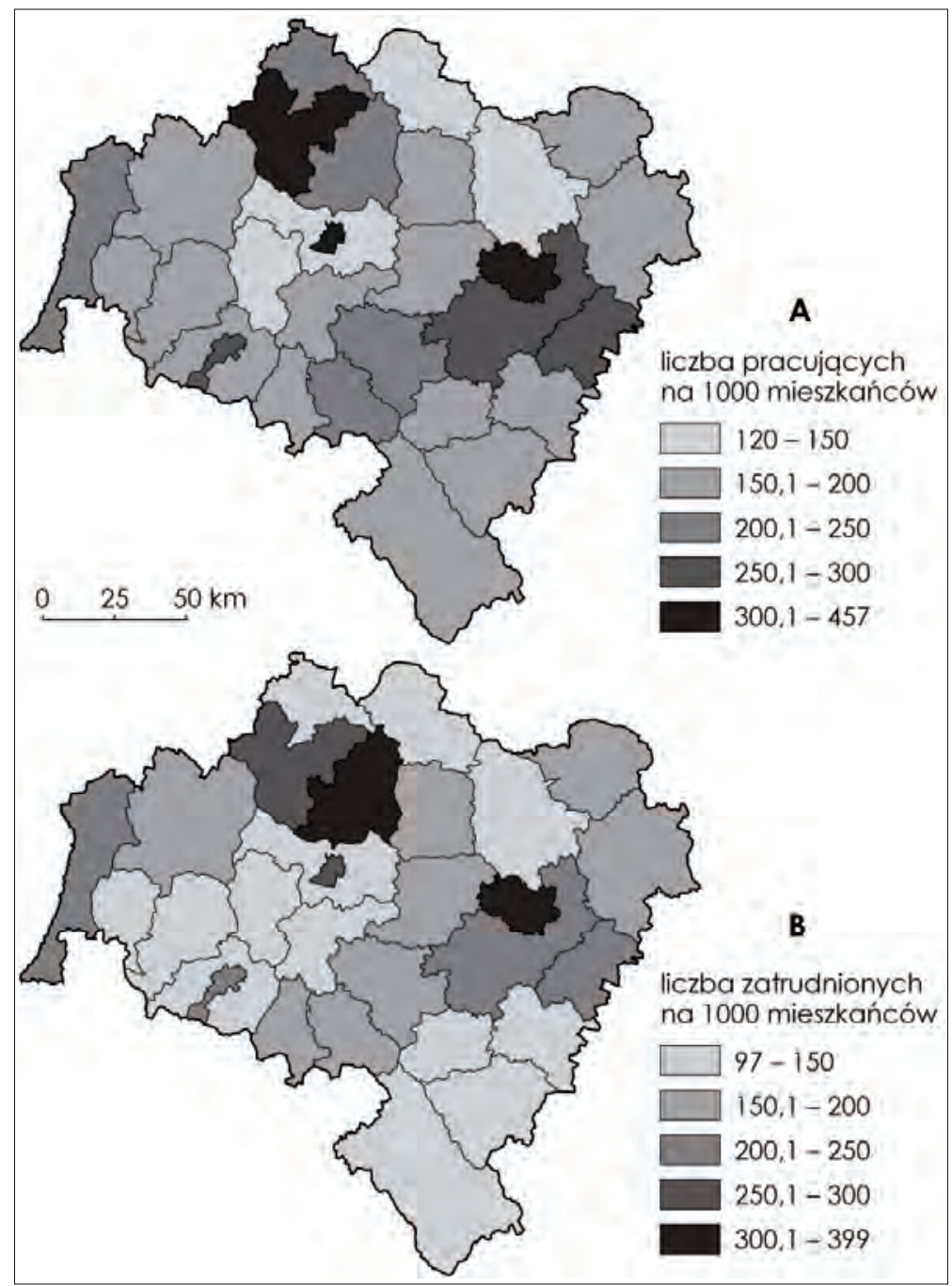

Ryc. 5. Pracujący (A) i zatrudnieni (B) w województwie dolnośląskim w $2008 \mathrm{r}$.

Źródło: opracowanie własne na podstawie Rocznik Statystyczny... 2003 oraz Województwo dolnoślaskie... $(2005,2006,2008,2009)$ 
jący powiaty: Wrocław, wrocławski, oławski, świdnicki i wałbrzyski, oraz drugi związany z Legnicko-Głogowskim Okręgiem Miedziowym, obejmujący powiaty: polkowicki, lubiński, głogowski i Legnicę. Obszary te należały przed okresem transformacji do najbardziej uprzemysłowionych na Dolnym Śląsku. Pomimo występujących na obszarze niektórych z nich (jak np. w powiatach świdnickim, wałbrzyskim) trudności na bazie wcześniejszych struktur gospodarczych, w jednostkach tych po restrukturyzacji utrzymały się na rynku lub powstały nowe podmioty gospodarcze (szerzej: Brezdeń, Spallek 2009). Nie bez znaczenia jest działalność podstref specjalnych stref ekonomicznych czy tworzone przez samorząd lokalny gminne strefy aktywności gospodarczej.

Obszary koncentracji zatrudnienia mają podobny rozkład przestrzenny jak koncentracja pracujących (ryc. 5B). Zwraca uwagę spadek intensywności zatrudnienia, mierzony liczbą zatrudnionych na 1000 mieszkańców, w dwóch obszarach: południowym, obejmującym powiat kłodzki, ząbkowicki, dzierżoniowski i strzeliński, oraz południowo-zachodnim, szczególnie w powiatach: jeleniogórskim, lwóweckim i lubańskim, które przesuwają się do klas o najniższych wartościach badanego zjawiska (por. ryc. 5A i 5B). Przeobrażenia, jakim ulegają w ostatnich latach wspomniane wyżej lokalne gospodarki powiatów, skutkują m.in. tym, iż zmniejsza się liczba miejsc pracy funkcjonujących na podstawie stosunku pracy, które często są charakterystyczne dla przedsiębiorstw. Jest to widoczne szczególnie na przykładzie powiatu lubińskiego, który z niższej klasy w wypadku pracujących przesunął się do najwyższej klasy w wypadku zatrudnienia. Opisana sytuacja jest efektem umiejscowienia na obszarze powiatu przedsiębiorstw oferujących miejsca pracy funkcjonujące na podstawie stosunku pracy i związane z przemysłem wydobywczym miedzi. Niekiedy likwidacja przedsiębiorstw w określonych obszarach, przy braku nowych projektów inwestycyjnych skutkuje częstszym pojawianiem się pracujących na własny rachunek (np. powiaty kłodzki i jeleniogórski). W efekcie liczba pracujących rośnie szybciej niż liczba zatrudnionych.

\section{BEZROBOCIE W REGIONIE}

Województwo dolnośląskie należy do regionów Polski o stosunkowo wysokim poziomie bezrobocia. Jest ono wynikiem restrukturyzacji regionalnej gospodarki, w której znaczącą rolę przed okresem transformacji odgrywał przemysł wydobywczy, metalowy, włókienniczy, a także w części zachodniej województwa rolnictwo uspołecznione. Na tych właśnie obszarach procesy restrukturyzacji skutkowały pojawianiem się znacznej liczby bezrobotnych.

Stopa bezrobocia w województwie dolnośląskim w 2009 r. wyniosła 12,5\%, podczas gdy dla całego kraju 11,9\%. Był to pierwszy rok ponownego jej wzrostu po okresie kilkuletniego spadku w regionie i w kraju w latach 2003-2008. Należy również zauważyć, że w tym okresie sytuacja na obszarach wiejskich regionu była szczególnie niekorzystna. Pomimo spadku ogólnej wielkości stopy bezrobocia jej poziom na wsi znacznie się zwiększył, osiagając wartość ponad 29\%. Od 2005 r. obserwujemy korzystną tendencję spadkową także na obszarach wiejskich.

Poziom stopy bezrobocia według płci w województwie kształtował się analogicznie do tendencji ogólnokrajowych, gdzie był wyższy wśród kobiet niż wśród mężczyzn. 
Cechą charakterystyczną był obniżający się poziom stopy bezrobocia dla wszystkich powiatów województwa w okresie 2004-2007 (ryc. 6). W niektórych powiatach niewielki wzrost stopy bezrobocia pojawił się już w 2008 r. Należały do nich powiaty lubański i kamiennogórski, gdzie przyczyną tego spadku była racjonalizacja zatrudnienia w kilku powstałych w ostatnich latach w specjalnej strefie ekonomicznej podmiotach należących do koncernów międzynarodowych, które szybciej odczuły efekty światowego kryzysu gospodarczego.

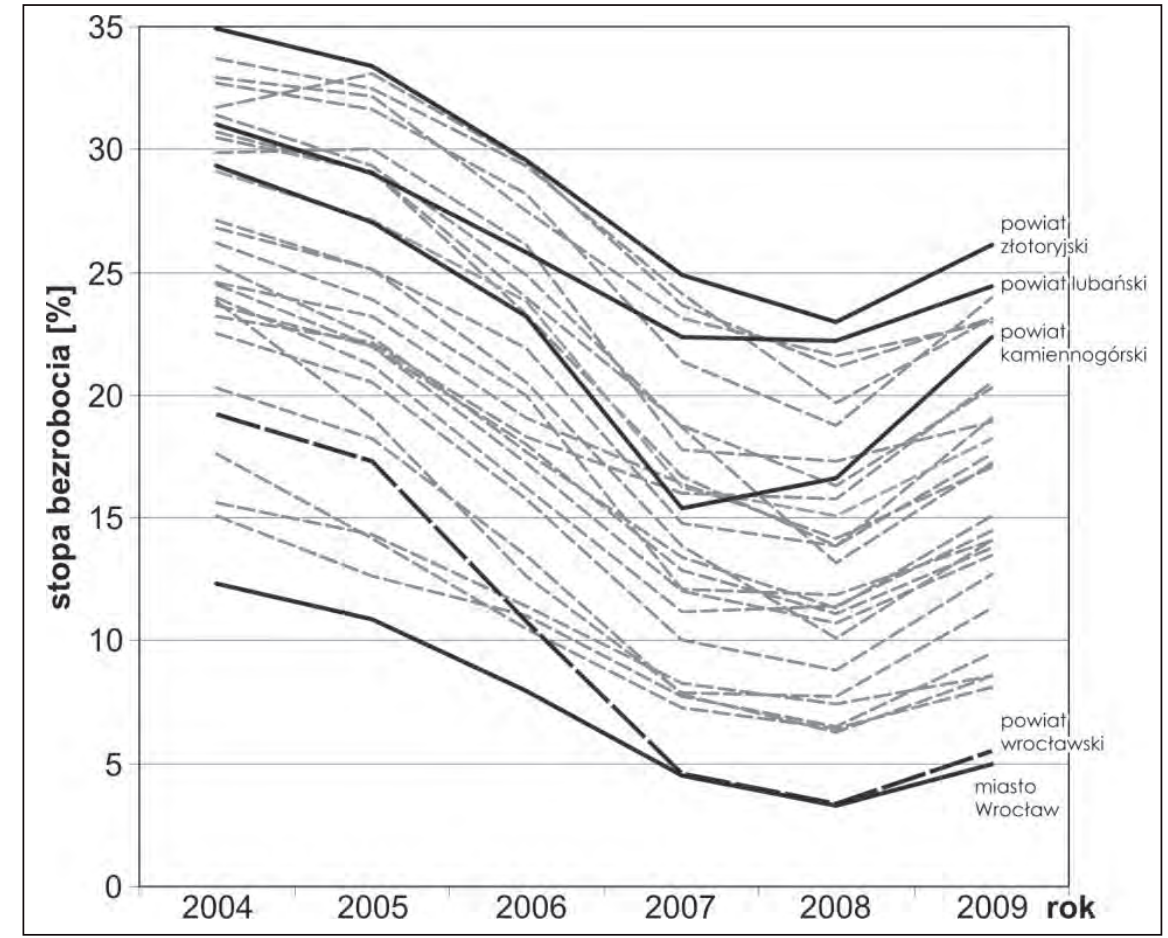

Ryc. 6. Zmiany stopy bezrobocia w powiatach województwa dolnośląskiego

Źródło: opracowanie własne na podstawie Banku danych regionalnych (www.stat.gov.pl)

W zdecydowanej większości powiatów wzrost stopy bezrobocia pojawił się dopiero w 2009 r. W rezultacie najwyższy jej poziom był charakterystyczny dla powiatów położonych w południowo-zachodniej i południowej części województwa, a więc na obszarach górskich i pogórza, z wyjątkiem Jeleniej Góry, oraz w dwóch powiatach części północnej regionu, tj. wołowskim i górowskim. Najwyższe wartości wskaźnika odnotowano w powiecie złotoryjskim, gdzie stopa bezrobocia wyniosła $26,1 \%$ przy średniej wojewódzkiej $12,5 \%$. Najniższe wartości występowały we Wrocławiu, Jeleniej Górze i Legnicy oraz powiatach: wrocławskim, polkowickim i lubińskim. W wymienionych jednostkach stopa bezrobocia kształtowała się na poziomie $5-10 \%$.

Analiza przestrzenna bezrobocia uwidacznia znaczną polaryzację regionu pod względem wykorzystania zasobów czynnika pracy w lokalnych gospodarkach (ryc. 7). Spowolnienie gospodarcze ujawniające się w 2009 r. wywołało efekt wyhamowania korzystnych zmian na lokalnych rynkach pracy. Szczególnie negatywny wpływ ma miejsce w jednostkach 
charakteryzujących się stosunkowo wysokim poziomem stopy bezrobocia i może znacznie utrudniać ich modernizację gospodarczą. Wyróżnić można obszary wygrywające jak aglomeracja wrocławska wraz z otaczającymi powiatami, powiaty wchodzące w skład Legnicko-Głogowskiego Okręgu Miedziowego wraz z Legnicą oraz Jelenia Góra. Pozostałe powiaty możemy zaliczyć do obszarów ,przegrywających”.

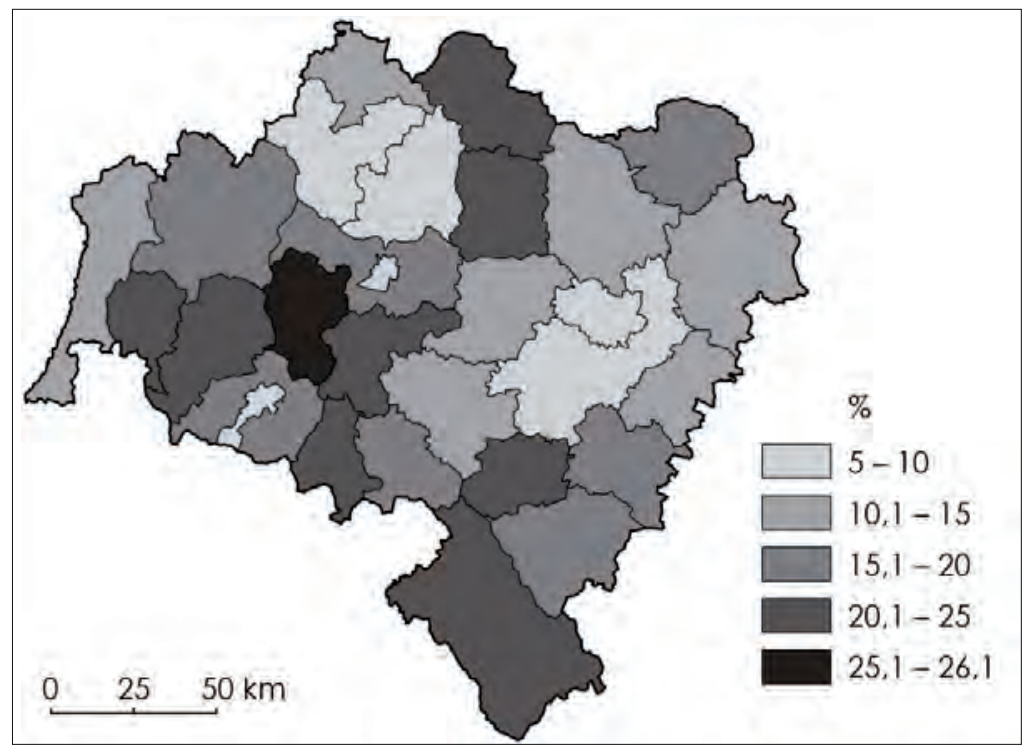

Ryc. 7. Stopa bezrobocia w województwie dolnośląskim w 2009 r.

Źródło: opracowanie własne na podstawie Banku danych regionalnych (www.stat.gov.pl)

Interesujących wniosków dostarcza analiza typów struktur bezrobotnych według grup ekonomicznych określona na podstawie trójkąta Osanna. Jako granicę typów struktur przyjęto wartości średnie krajowe udziału bezrobotnych w trzech podstawowych grupach wiekowych: poniżej 24, 25-44 i 45 i więcej lat (ryc. 8). Na obszarze województwa dolnośląskiego w 2008 r. zidentyfikowano cztery typy struktur (typ III, IV, V i VI). Najliczniejszą grupę (18 jednostek) stanowiły powiaty o strukturze $\mathrm{z}$ dominacją bezrobotnych powyżej 45 roku życia, zlokalizowane w części południowej i południowo-zachodniej województwa. Wykazywały one wyższy udział tej grupy wiekowej bezrobotnych niż średnia dla kraju. Na tej podstawie możemy stwierdzić, że w województwie dolnośląskim występują relatywnie większe trudności w aktywizacji bezrobotnych w wieku powyżej 45 lat niż przeciętnie w kraju. Z drugiej strony wspomniane powiaty charakteryzowały się niższym od przeciętnego w kraju udziałem ludności młodej wśród populacji bezrobotnych, co na pewno jest zjawiskiem pozytywnym.

Kolejną grupę stanowiły powiaty ze współdominacją w strukturze wiekowej bezrobotnych powyżej 45 roku życia jak i ludności młodej (typ IV). Należały do nich powiaty we wschodniej części województwa - milicki, oleśnicki i oławski, centralnej - wołowski i średzki oraz zachodniej - bolesławiecki i zgorzelecki. Ich rynek pracy wykazywał większą absorpcję bezrobotnych w wieku 25-44 lat niż przeciętna dla Polski. Przeprowadzona analiza uwypukla istnienie ważnego problemu w absorpcji na rynku pracy regionu bezrobotnych powyżej 45 roku życia. 


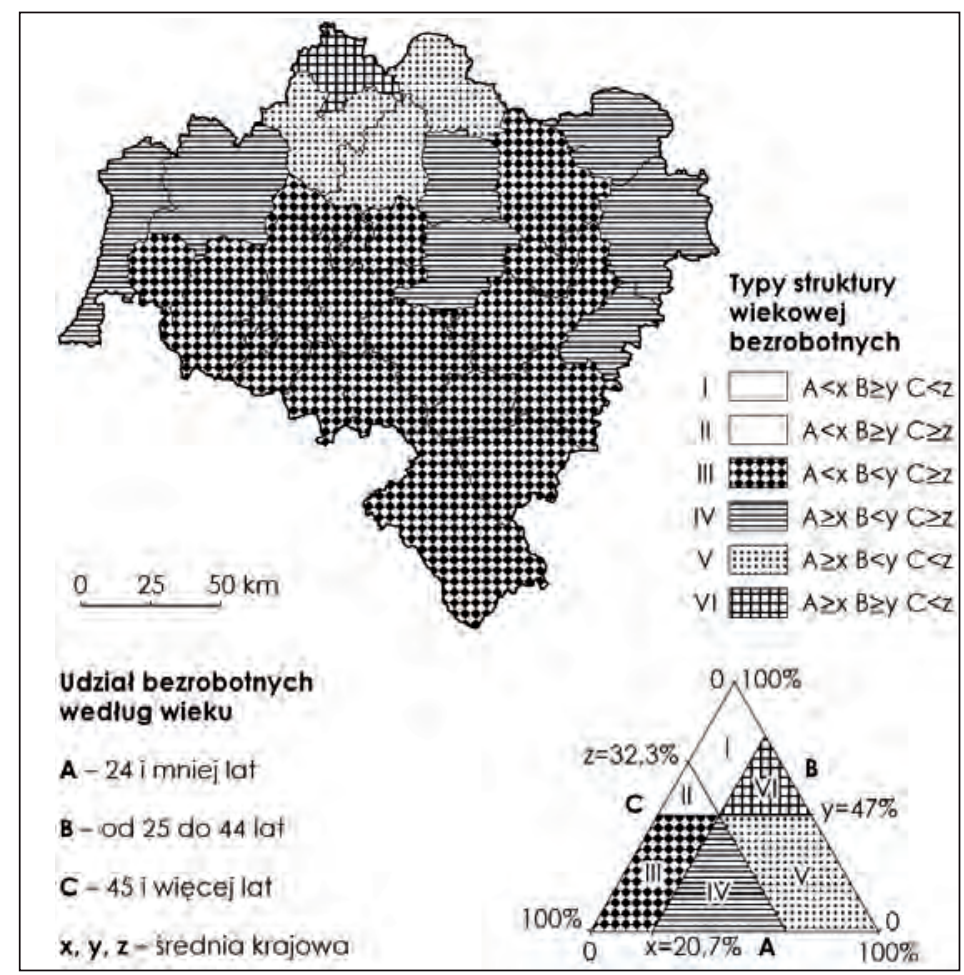

Ryc. 8. Typologia bezrobotnych według wieku w województwie dolnośląskim w $2008 \mathrm{r}$.

(dla średniej krajowej)

Źródło: opracowanie własne na podstawie Rocznik Statystyczny... 2003 oraz Województwo dolnoślaskie... (2005, 2006, 2008, 2009)

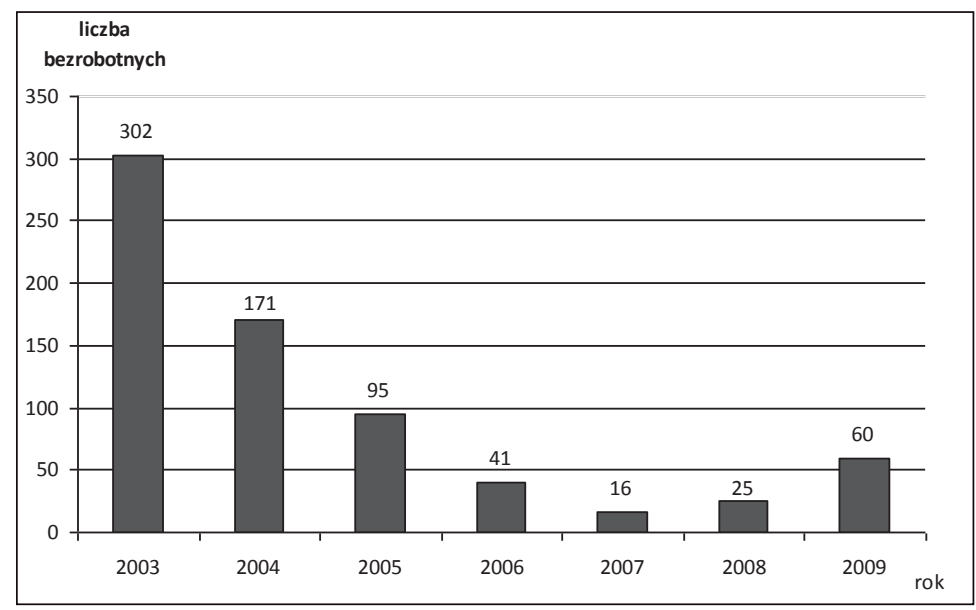

Ryc. 9. Liczba bezrobotnych na 1 ofertę pracy w województwie dolnośląskim w latach 2003-2009

Źródło: opracowanie własne na podstawie Rocznik Statystyczny... 2003 oraz Województwo dolnoślaskie... $(2005,2006,2008,2009)$ 
Zmniejszającej się liczbie bezrobotnych w latach 2003-2007 towarzyszyła zwiększająca się na rynku liczba ofert pracy zgłaszanych przez pracodawców. Te korzystne zmiany wynikały z ogólnokrajowej, sprzyjającej koniunktury gospodarczej, uruchamiającej procesy inwestycyjne. Spowodowały one zwiększoną absorpcję siły roboczej na wielu lokalnych rynkach województwa. Jej skutkiem była zmniejszająca się liczba bezrobotnych przypadających na 1 ofertę pracy. Ta korzystna tendencja uległa odwróceniu od 2008 r. (ryc. 9). Jej przyczyną była zmniejszająca się liczba ofert pracy w regionie oraz wzrastająca od $2009 \mathrm{r}$. liczba bezrobotnych. Niska wartość wskazanego parametru może świadczyć o dużej elastyczności rynku i znacznej podaży miejsc pracy ułatwiającej bezrobotnym szybsze i łatwiejsze znalezienie pracy. Pod tym względem rynek pracy województwa był zróżnicowany (ryc. 10). Najmniejsza liczba bezrobotnych na 1 ofertę pracy występowała w części wschodniej i południowo-wschodniej regionu, związanej z oddziaływaniem aglomeracji wrocławskiej, a także na obszarze powiatów związanych z LGOM. Najgorsza sytuacja miała miejsce w południowo-zachodniej części województwa, szczególnie w powiatach lwóweckim i jeleniogórskim oraz na północy w powiecie górowskim. Jednostki te charakteryzowały się jednocześnie wysokim poziomem stopy bezrobocia.

Powyższe zjawisko jest kolejnym przejawem zaznaczającego się w regionie spowolnienia gospodarczego. Jego szczególnie negatywny efekt uwidacznia się w powiatach, w których nie zakończyły się jeszcze procesy restrukturyzacji ich lokalnych gospodarek.

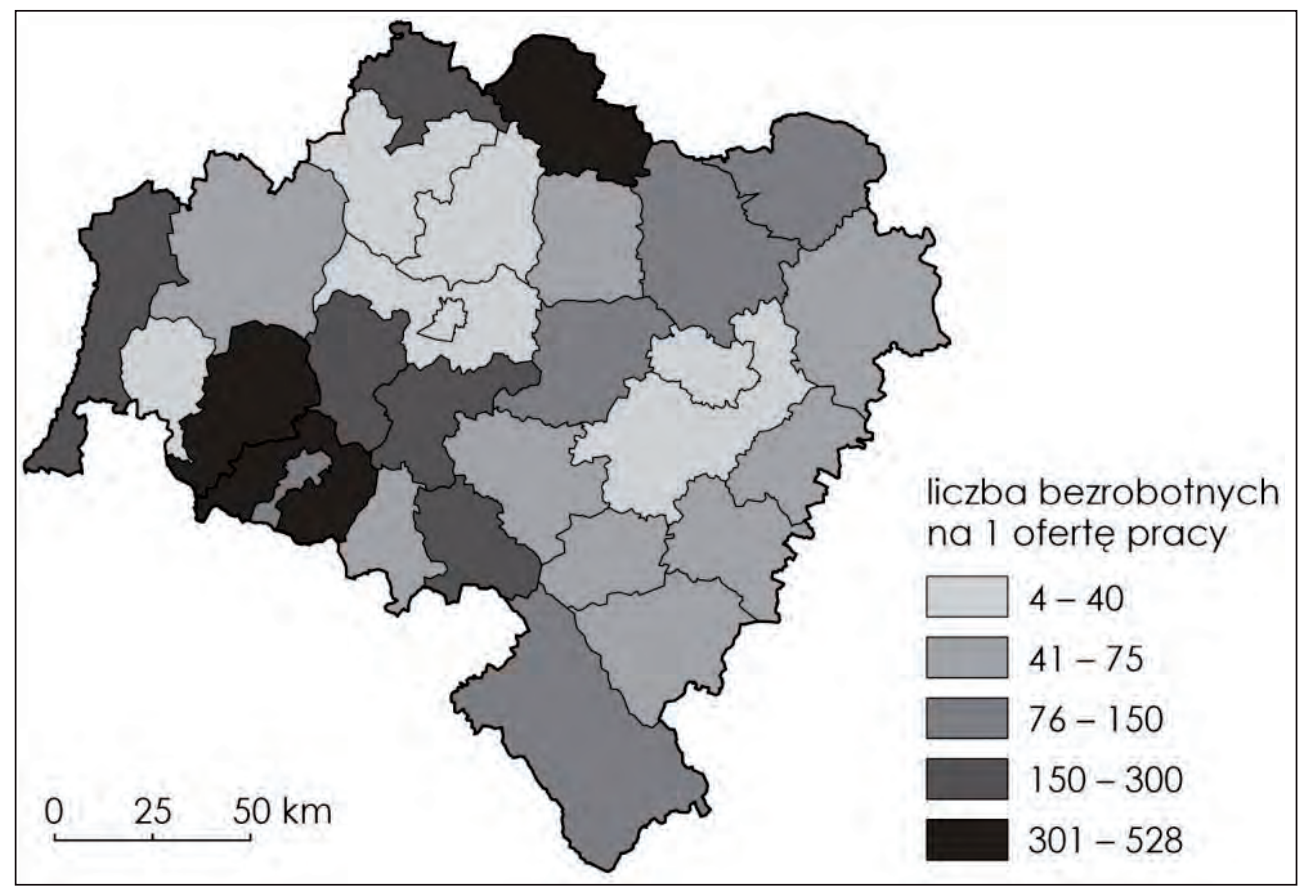

Ryc. 10. Oferty pracy województwie dolnośląskim w $2008 \mathrm{r}$.

Źródło: opracowanie własne na podstawie Rocznik Statystyczny... 2003 oraz Województwo dolnoślqskie... (2005, 2006, 2008, 2009) 


\section{KONKURENCYJNOŚĆ POWIATÓW POD WZGLEDEM RYNKU PRACY}

Do analizy konkurencyjności powiatów Dolnego Śląska, pod względem sytuacji na rynku pracy zastosowano taksonomiczną metodę porządkowania liniowego (Konkurencyjność powiatów... 2006). Hierarchię obiektów określa się na podstawie ich odległości od tzw. wzorca rozwoju. Analize przeprowadzono w oparciu o wskaźniki diagnostyczne charakteryzujące sytuację na rynku pracy pod względem zatrudnienia (liczba pracujących na 1000 mieszkańców, udział zatrudnionych w sektorze prywatnym, udział zatrudnionych w usługach, udział zatrudnionych w rolnictwie, przeciętne miesięczne wynagrodzenie brutto) oraz bezrobocia (poziom stopy bezrobocia, udział długotrwale bezrobotnych w ogólnej liczbie niepracujących, różnica wskaźników: udział zarejestrowanych bezrobotnych z wyższym wykształceniem i udział osób bezrobotnych z wykształceniem gimnazjalnym i niższym, liczba ofert pracy na 1000 zarejestrowanych bezrobotnych, różnica wskaźników: liczba nowo zarejestrowanych bezrobotnych (napływ) i liczba wyrejestrowanych bezrobotnych (odpływ) w 2009 r. na 100 zarejestrowanych bezrobotnych.

Skumulowany miernik rynku pracy obejmujący ocenę sytuacji pod względem zatrudnienia i bezrobocia przyjmuje wartości od 2,8 do 6,1. Jego rozkład przestrzenny jest znacznie zróżnicowany (ryc. 11). Analiza jego zmienności pozwala na wydzielenie trzech obszarów charakteryzujących się najkorzystniejszą sytuacją na rynku pracy. Są to: Wrocław i jego bezpośrednie otoczenie, powiaty: polkowicki, lubiński i Legnica oraz Jelenia Góra. Najtrudniejsza sytuacja panuje na rynku pracy w południowej części województwa (powiat kłodzki, ząbkowicki i dzierżoniowski), w północnej części (powiat wołowski, milicki i górowski) oraz w dwóch powiatach południowo-zachodniej części regionu (lubańskim i złotoryjskim).

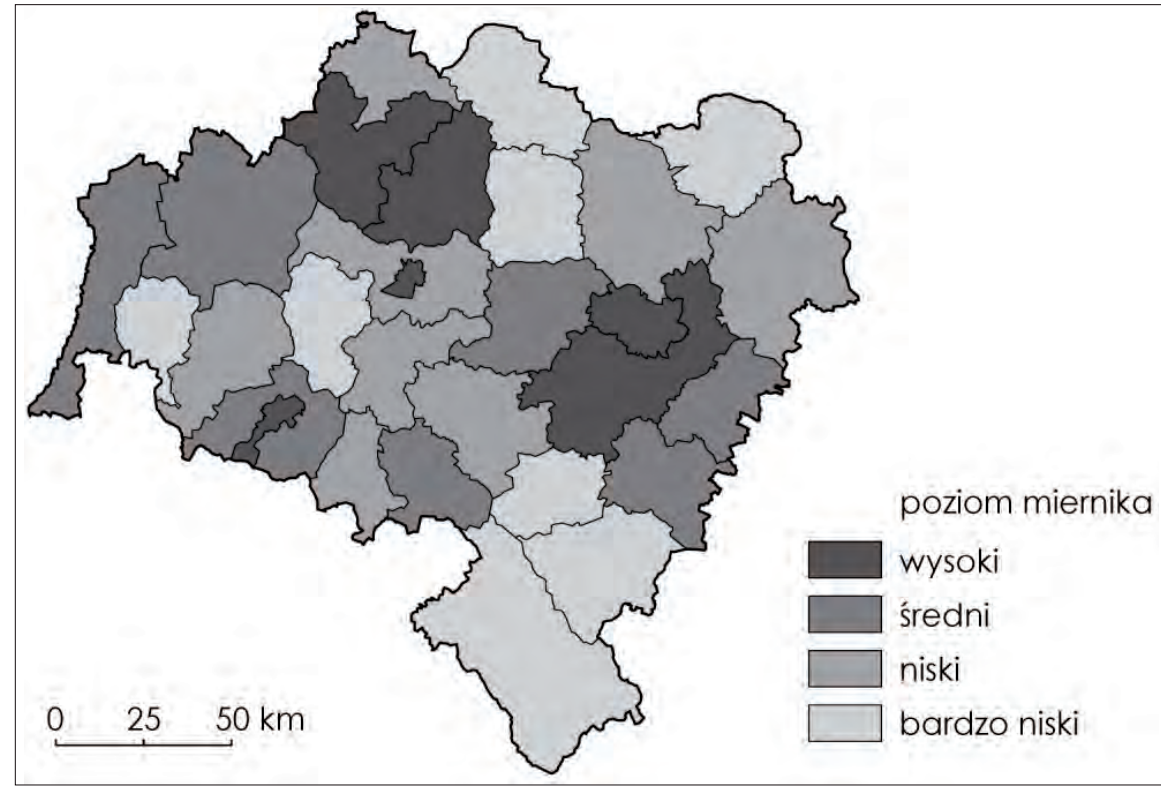

Ryc. 11. Konkurencyjność powiatów - rynek pracy - miernik syntetyczny

Źródło: opracowanie własne na podstawie: Województwo dolnoślaskie... $(2008,2009)$ 


\section{Podsumowanie}

Przeprowadzone analizy rynku pracy województwa dolnośląskiego dla lat 2000-2008 wskazują na obniżanie się wskaźnika aktywności zawodowej ludności pomimo wzrostu liczby pracujących. Pozytywnym aspektem rozwoju regionalnego rynku pracy jest wzrost poziomu wskaźnika zatrudnienia pomimo spowolnienia gospodarczego. Przeprowadzona analiza przestrzenna rynku pracy na podstawie miernika syntetycznego uwidacznia znaczną polaryzację regionu pod względem wykorzystania zasobów czynnika pracy w lokalnych gospodarkach.

Zasadniczym efektem spowolnienia gospodarczego w regionie jest wzrost stopy bezrobocia oraz obniżająca się liczba oferowanych miejsc pracy. Spowolnienie gospodarcze wywołało efekt wyhamowania korzystnych zmian na lokalnych rynkach pracy województwa. Szczególnie negatywny jego wpływ ma miejsce w jednostkach charakteryzujących się stosunkowo wysokim poziomem stopy bezrobocia i może znacznie utrudniać ich modernizację gospodarczą.

\section{Literatura}

Brezdeń P., Spallek W., 2009, Efektywność firm korporacyjnych o dobrym standingu w województwie dolnoślaskim w ujęciu przestrzennym, [w:] Problemy ksztaltowania się przestrzennych struktur przemystowych i ich otoczenia, red. Z. Zioło, T. Rachwał, Prace Komisji Geografii Przemysłu PTG, nr 14, Warszawa-Kraków, s. 81-94.

Hildebrant A., 2003, Profil wrażliwości gospodarki regionalnej na integrację z Uniq Europejska. Województwo dolnoślaskie, Instytut Badań Nad Gospodarką Rynkową, Gdańsk.

www.stat.gov.pl, http://www.stat.gov.pl/bdr_n/app/strona.indeks, ostatni dostęp 22.11.2010 r.

Konkurencyjność powiatów województwa dolnoślaskiego w latach 1999-2004, 2006, Analizy statystyczne, Urząd Statystyczny we Wrocławiu, Wrocław.

Rocznik Statystyczny Województwa Dolnoślaskiego 2003, 2003, Urząd Statystyczny, Wrocław.

Województwo dolnoślaskie. Podregiony, powiaty, gminy 2005, 2005, Urząd Statystyczny, Wrocław.

Województwo dolnoślaskie. Podregiony, powiaty, gminy 2006, 2006, Urząd Statystyczny, Wrocław.

Województwo dolnoślaskie. Podregiony, powiaty, gminy 2008, 2008, Urząd Statystyczny, Wrocław.

Województwo dolnoślaskie. Podregiony, powiaty, gminy 2009, 2009, Urząd Statystyczny, Wrocław.

\section{The labour market of lower-silesian voivodeship during the economic slowdown}

The article focuses on processes of the regional labor market during the economic slowdown that resulted from the global financial crisis in years 2007-2009, which is also called the Great Recession.

The labor market's situation is the result of the interaction of many complex processes. On the one hand, it is a derivative of the level of development and structure of the economy; on the other hand, the shape of the labor market is influenced by the changes associated with an ever-increasing integration of Poland with the European Union.

In recent years, global economic processes, especially connected with the Great Recession, also play a significant role in shaping the situation of regional labor markets. 
The article presents the trends of development of the labor market in the region in years 20002009 in the field of economic activity and employment rates taking into consideration the selected demographic and economic categories of the population. The particular attention is devoted to the issues of development of unemployment and its typology. These elements of the labor market were presented in the local systems of the region with an indication of their spatial variation and intensity.

On the basis of identified regularity of development of the studied phenomenon, the authors made an attempt to identify and evaluate the impact of the economic slowdown on the regional labor market at the local and regional level.

dr Paweł Brezdeń

Uniwersytet Wrocławski

Instytut Geografii i Rozwoju Regionalnego

Zakład Analiz Regionalnych i Lokalnych

e-mail: pawel.brezden@uni.wroc.pl

dr Waldemar Spallek

Uniwersytet Wrocławski

Instytut Geografii i Rozwoju Regionalnego

Zakład Kartografii

e-mail: waldemar.spallek@uni.wroc.pl 